\title{
Systems to increase grazeable forage production in the Waikato: A progress report on the tall fescue and perennial ryegrass component of these systems
}

\author{
C.E.F. CLARK ${ }^{1}$, D.A. CLARK ${ }^{1}$, C.D. WAUGH ${ }^{1}$, C.G. ROACH ${ }^{1}$, C.B. GLASSEY ${ }^{1}$, \\ S.L. WOODWARD ${ }^{1}$, E.M.K. MINNEE ${ }^{1}$ and D.R. WOODFIELD ${ }^{2}$ \\ ${ }^{1}$ DairyNZ, Private Bag 3221, Hamilton 3204 \\ ${ }^{2}$ AgResearch, Tennant Drive, Private Bag 11008, Palmerston North \\ cameron.clark@dairynz.co.nz
}

\begin{abstract}
Grazed forage underpins the productivity and economic performance of New Zealand's pastoral industries. This trial aimed to increase grazeable forage grown by $50 \%$ from 17 to $25 \mathrm{t} \mathrm{DM} /$ ha to meet industry targets. Six treatments consisting of different combinations of pasture species were established in March 2008 with the objective of increasing grazeable forage production by using irrigation, phosphate fertiliser and nitrogen, standoff, new cultivars of ryegrass ('Alto' perennial ryegrass containing AR1 endophyte) and alternative forages such as 'Advance' tall fescue with Max $\mathrm{P}^{\circledR}$ endophyte, chicory (cv. 'Choice') or lucerne (cv. 'P54Q53'). The yield of perennial ryegrass was greater than tall fescue in the winter of 2008 (Year 1) and 2009 (Year 2). Tall fescue tended to have a greater summer yield than perennial ryegrass, although this effect was inconsistent between years. Irrigation increased the yield of tall fescue by $50 \%$ and perennial ryegrass by $13 \%$ in Year 2. Mean yield of milksolids for the six treatments over 2 years was 1371 for perennial ryegrass and $1310 \mathrm{~kg} \mathrm{MS} / \mathrm{ha}$ for tall fescue treatments.
\end{abstract}

Keywords: dry matter production, irrigation

\section{Introduction}

The New Zealand dairy industry has set a target (DairyNZ 2009) of increasing forage eaten per ha by $50 \%$ and forage grown from 17 to $25 \mathrm{t} \mathrm{DM} / \mathrm{ha}$ in current top-performing commercial and research farms. Due to the limitations of light and temperature, potential Waikato perennial ryegrass (Lolium perenne) production has been estimated as $24 \mathrm{t} \mathrm{DM} / \mathrm{ha}$ (Mitchell 1963). To reach $25 \mathrm{t} \mathrm{DM/ha,} \mathrm{use} \mathrm{of} \mathrm{alternative} \mathrm{species,}$ with morphology and physiology better suited to Waikato environmental conditions will be required to complement, or replace, the traditional perennial ryegrass/white clover (Trifolium repens) - based pastures.

Summer pasture growth in the Waikato region of New Zealand is highly variable compared with other seasons, predominantly due to variable rainfall (Baars 1976). On average, evaporation exceeds rainfall between November and March leading to a deficit in soil moisture. Increasing soil moisture through irrigation and/or incorporating alternative forages, with deeper penetrating root systems and physiology better suited than perennial ryegrass to summer dry conditions, may increase grazeable forage production. Thom et al. (2001) found irrigation increased perennial ryegrass production by $1-2 \mathrm{t} \mathrm{DM} / \mathrm{ha} / \mathrm{yr}$ over 4 years. Relative to perennial ryegrass, continental tall fescue (Festuca arundinacea) tends to be more productive during dry summers (Kemp et al. 1999).

The objective of this work was to increase grazeable forage production to $25 \mathrm{t} \mathrm{DM} / \mathrm{ha} / \mathrm{yr}$ by removing location-specific limitations to growth with strategic use of irrigation, $\mathrm{N}$ fertiliser, a standoff pad, and by evaluating the pasture growth and milksolids (MS) production from alternative species to perennial ryegrass such as tall fescue, chicory and lucerne. This paper reports on the dry matter yield of tall fescue and perennial ryegrass within these systems.

\section{Materials and Methods}

The trial was conducted at Scott Farm, DairyNZ, near Hamilton, New Zealand $\left(37^{\circ} 47^{\prime} \mathrm{S} 175^{\circ} 19^{\prime} \mathrm{E}\right.$; elevation $40 \mathrm{~m}$ a.s.1.).

\section{Design}

The trial site was initially 30 ha in the 2008/2009 season on Bruntwood, Horotiu, Te Rapa peaty and humic, Te Kowhai and Matangi silt loam soils (New Zealand classification; Hewitt 1998). In the 2009/2010 season, (Year 2) the total area of the treatments was reduced to 24 ha with 1 ha of pasture dropped from each treatment due to funding constraints. Paddocks were randomly allocated within soil type to treatments ensuring balance for soil type. Treatments in the 2008/2009 season were:

A. Perennial ryegrass (cv 'Alto' AR1) mixed with white clover (cv. 'Kopu II') (5 ha)

B. Tall fescue (cv. 'Advance' Max $\mathrm{P}^{\circledR}$ ) mixed with white clover (cv. 'Kopu II') (5 ha)

C. Perennial ryegrass (cv. 'Alto' AR1) (4 ha) with chicory (cv. 'Choice') and red clover (cv. 'Sensation') (Trifolium pratense) (1ha) 
D. Tall fescue (cv. 'Advance' Max $\left.\mathrm{P}^{\circledR}\right)$ (4 ha) with chicory (cv. 'Choice') and red clover (cv. 'Sensation') (1 ha)

E. Perennial ryegrass (cv. 'Alto' AR1) (4 ha) with lucerne (cv. 'P54Q53') (1 ha)

F. Tall fescue (cv. 'Advance' Max $\left.\mathrm{P}^{\circledR}\right)$ (4 ha) with lucerne (cv.'P54Q53') (1 ha).

\section{Establishment}

During January 2008, 26 ha of existing perennial ryegrass pasture was sprayed with 5 L Glyphosate 510/ha and wetting agent, and was ploughed and powerharrowed following application of lime $(2.5 \mathrm{t} / \mathrm{ha})$ and fertiliser $(650 \mathrm{~kg} / \mathrm{ha} \mathrm{30 \%}$ Potash Sulphur Super; requirements based on September 2007 soil tests). Weeds that germinated post-cultivation were resprayed with $5 \mathrm{~L}$ Glyphosate/ha and wetting agent. The grass component of the six treatments was sown by Cambridge roller-drill from 10 to 13 March 2008 at a mean rate (including Superstrike seed treatment) of $18 \mathrm{~kg}$ ryegrass $/$ ha for treatments $\mathrm{C}$ and $\mathrm{E}, 15 \mathrm{~kg}$ ryegrass/ha with $5 \mathrm{~kg}$ white clover/ha for treatment A, $25 \mathrm{~kg}$ tall fescue/ha for treatments D and F, $24 \mathrm{~kg}$ tall fescue with $5 \mathrm{~kg}$ white clover/ha for treatment B. Broad-leaved weeds were sprayed using 2, 4-D amine ('Baton') at $1.5 \mathrm{~kg} / \mathrm{ha}$ onto non-clover treatments on 13 May. Additionally, $2.5 \mathrm{~L} / \mathrm{ha}$ Nortron was sprayed onto all tall fescue paddocks on 11 June to eliminate Poa аппиа competition with tall fescue seedlings.

\section{Management}

In the 2008/2009 season (Year 1) all 26 ha of grass paddocks were irrigated with $170 \mathrm{~mm}$ of bore water by travelling big-gun irrigators. Paddocks were irrigated when soil moisture levels fell to less than $75 \%$ of field capacity, with $25 \mathrm{~mm}$ per application. Bore water $(390$ $\mathrm{mm}$ ) was applied to irrigated paddocks in the 2009/2010 season when only two hectares of pasture were irrigated on each treatment to utilise available water resources more effectively and allow a comparison of unirrigated versus irrigated pasture production.

When the soil moisture level was high in the drainage season (May to July), cows were strategically offered pasture before their removal from grazed paddocks to a plastic lined, woodchip surfaced standoff pad to minimise pasture damage.

Fertiliser was applied according to the recommendations for the paddock with the lowest soil test to ensure non-limiting soil nutrient levels (Roberts \& Morton 1999). Nitrogen, as urea, was applied after grazing ( 25 to $50 \mathrm{~kg} \mathrm{~N} / \mathrm{ha}$ per application as per Ball (1970)).

\section{Animals}

Ninety-six Holstein-Friesian cows were randomly allocated to treatments from 1 June 2008 based on age (mean $5.1 \mathrm{yrs}$ ), expected calving date (mean 27 July 2008), liveweight (mean $503 \mathrm{~kg}$ ), body condition score (BCS) (mean 4.0) and previous season's MS production (mean $338 \mathrm{~kg}$ ). Twenty-four Holstein-Friesian heifers were also allocated to farmlets based on liveweight (mean $405 \mathrm{~kg}$ ) and expected calving date (mean 26 July 2008). This initial number of cows equated to an expected comparative stocking rate of $85 \mathrm{~kg}$ liveweight $/ \mathrm{t}$ DM (Penno 1999) (4 cows/ha) based on a forage yield of $25 \mathrm{t} \mathrm{DM} / \mathrm{ha}$. The stocking rate across all treatments was reduced to 3.5 cows/ha in the 2009/2010 season.

\section{Measurements}

Three methods were used to determine pasture yield in both Years 1 and 2: weekly calibrated visual estimation of herbage mass, back calculation based on MS production data and standard cow energetic requirements, and cage cuts. For the purposes of this progress report only the cage cut data are presented.

Cages (one per 0.5 ha paddock) were trimmed to $2 \mathrm{~cm}$ in Year 1 before cage placement each month. Accumulated herbage was cut to $2 \mathrm{~cm}$ within a 0.2 $\mathrm{m}^{2}$ quadrat before oven-drying at $95^{\circ} \mathrm{C}$ and weighing. In Year 2 cages were trimmed to $4 \mathrm{~cm}$ before cage placement and accumulated herbage cut to $4 \mathrm{~cm}$. Cutting height was changed in Year 2 because the research of Lee et al. (2008) showed the negative impact of cutting to $2 \mathrm{~cm}$ on subsequent grass growth.

Chicory/red clover and lucerne growth was determined by $6 \times 0.2 \mathrm{~m}^{2}$ quadrat cuts per paddock (considered as 1 ha area of crop in 2008/2009 and 0.5 ha in 2009/2010) before grazing.

\section{Statistical analysis}

The pasture component data of each treatment were analysed for this progress report. Individual paddock growth data within each farmlet were analysed using mixed models fitted using REML with treatment main effects and interactions included as fixed effects and paddock as a random effect. Paddock was the experimental unit.

\section{Results}

\section{Rainfall, temperature and sunshine hours}

The mean daily rainfall for each season, air temperature and mean total sunshine hours for Years 1 and 2 are compared with the 30-year mean (1979-2009) for the Ruakura Climatological Station (5 km west of the trial site) (Table 1). Relative to the $30 \mathrm{yr}$ mean, Year 1 was characterised by high winter rainfall and low sunshine hours/d, high summer rainfall and low autumn rainfall. Year 2 had below average autumn rainfall $(1.1 \mathrm{~mm} / \mathrm{d}$ 
Table 1 Seasonal mean daily rainfall $(\mathrm{mm} / \mathrm{d})$, air temperature $\left({ }^{\circ} \mathrm{C}\right)$ and total sunshine $(\mathrm{h} / \mathrm{d})$ for 2008/2009 and $2009 / 2010$ and the 30-year mean (1979-2009) (Ruakura Climatological Station).

\begin{tabular}{|c|c|c|c|c|c|c|c|c|c|}
\hline & \multicolumn{3}{|c|}{ Rainfall (mm/d) } & \multicolumn{3}{|c|}{ Air temperature $\left({ }^{\circ} \mathrm{C}\right)$} & \multicolumn{3}{|c|}{ Total sunshine $(\mathrm{h} / \mathrm{d})$} \\
\hline & $2008 / 9$ & $2009 / 10$ & $\begin{array}{l}30 \mathrm{yr} \\
\text { mean }\end{array}$ & $2008 / 9$ & $2009 / 10$ & $\begin{array}{l}30 \mathrm{yr} \\
\text { mean }\end{array}$ & $2008 / 9$ & $2009 / 10$ & $\begin{array}{l}30 \mathrm{yr} \\
\text { mean }\end{array}$ \\
\hline Winter & 5.9 & 3.8 & 3.9 & 9.5 & 8.7 & 9.4 & 4.0 & 4.6 & 4.3 \\
\hline Spring & 2.9 & 3.2 & 3.1 & 13.1 & 12.3 & 13.1 & 5.9 & 5.7 & 5.9 \\
\hline Summer & 3.5 & 3.1 & 2.9 & 18.2 & 18.1 & 18.0 & 7.2 & 6.8 & 7.4 \\
\hline Autumn & 2.2 & 1.1 & 2.9 & 13.9 & 13.7 & 14.5 & 6.5 & 5.7 & 5.5 \\
\hline
\end{tabular}

compared with the 30 year mean of $2.9 \mathrm{~mm} /$ day).

\section{Forage yield}

From establishment through winter of Year 1, perennial ryegrass yield was on average $70 \%$ greater $(\mathrm{P}<0.001)$ than tall fescue yield (Table 2). For the same period there was an interaction between grass type and treatment with perennial ryegrass yield tending to be greater in treatments with chicory and lucerne relative to perennial ryegrass mixed with white clover. In contrast, the yield of tall fescue in summer was on average $20 \%$ greater $(\mathrm{P}<0.05)$ than the yield of perennial ryegrass. Perennial ryegrass and tall fescue yields were similar in spring and autumn of Year 1. The total yields of irrigated perennial ryegrass and tall fescue were similar in Year 1.

For Year 2, yield of perennial ryegrass in winter was $70 \%$ greater $(\mathrm{P}<0.001)$ than yield of tall fescue (Table $2)$. Tall fescue and perennial ryegrass yields were similar $(\mathrm{P}>0.05)$ for all other seasons. The total yields of tall fescue and perennial ryegrass were similar in Year 2.

Irrigation increased pasture yield by $20 \%(0.9 \mathrm{t} \mathrm{DM} /$ ha; $\mathrm{P}<0.05)$ and $120 \%(2.0 \mathrm{t} \mathrm{DM} / \mathrm{ha})(\mathrm{P}<0.001)$ in the summer and autumn of Year 2, respectively. Irrigation increased total yield of tall fescue by $50 \%(5.4 \mathrm{t} \mathrm{DM} /$

Table 2 Seasonal mean total yield by cage cut (t DM/ha) and nitrogen $(N)$ application $(\mathrm{kg} / \mathrm{ha})$ for grass (G) type (perennial ryegrass, tall fescue) within each treatment ( $\mathrm{T}$ ( (PrCl: perennial ryegrass mixed with white clover, TfCl: tall fescue mixed with white clover, PrCh: perennial ryegrass (chicory/red clover as a crop), TfCh: tall fescue (chicory/red clover as a crop), PrL: perennial ryegrass (lucerne as a crop), TfL: tall fescue (lucerne as a crop) when unirrigated (U) in the 2008/2009 and $2009 / 2010$ seasons and irrigated (I) in the $2009 / 2010$ season.

\begin{tabular}{|c|c|c|c|c|c|c|c|c|c|c|c|c|c|c|c|c|c|c|c|c|}
\hline & \multicolumn{6}{|c|}{ Perennial ryegrass } & \multicolumn{6}{|c|}{ Tall fescue } & \multirow[b]{3}{*}{ sed } & \multirow[b]{3}{*}{$\mathrm{G}$} & \multirow[b]{3}{*}{$\mathrm{T}$} & \multicolumn{3}{|c|}{$\mathrm{P}$-value } & \multirow[b]{3}{*}{$I^{*} T$} & \multirow[b]{3}{*}{$I^{*} G^{*} T$} \\
\hline & \multicolumn{2}{|c|}{$\mathrm{PrCl}$} & \multicolumn{2}{|c|}{ PrCh } & \multicolumn{2}{|c|}{ PrL } & \multicolumn{2}{|c|}{$\mathrm{TfCl}$} & \multicolumn{2}{|c|}{ TfCh } & \multicolumn{2}{|c|}{ TfL } & & & & & & & & \\
\hline & 1 & $U$ & I & $U$ & 1 & $U$ & 1 & $U$ & I & $U$ & 1 & $U$ & & & & $G^{*} T$ & 1 & $I^{\star} G$ & & \\
\hline \multicolumn{21}{|l|}{$2008 / 2009$} \\
\hline Winter $^{1}$ & 3.9 & & 4.0 & & 4.7 & & 2.8 & & 2.5 & & 2.2 & & 0.4 & 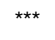 & NS & * & & & & \\
\hline Spring & 5.5 & & 6.1 & & 6.4 & & 5.3 & & 5.6 & & 5.5 & & 0.7 & NS & NS & NS & & & & \\
\hline Summer & 5.5 & & 4.7 & & 5.3 & & 6.2 & & 6.7 & & 5.6 & & 0.7 & * & NS & NS & & & & \\
\hline Autumn & 3.0 & & 3.6 & & 3.9 & & 3.2 & & 3.3 & & 3.1 & & 0.4 & NS & NS & NS & & & & \\
\hline Total & 16.8 & & 17.3 & & 18.5 & & 16.6 & & 17.4 & & 15.7 & & 1.3 & NS & NS & NS & & & & \\
\hline $\mathrm{N}$ application & 398 & & 545 & & 471 & & 361 & & 488 & & 499 & & & & & & & & & \\
\hline \multicolumn{21}{|l|}{$2009 / 2010$} \\
\hline Winter & 2.4 & 2.3 & 1.8 & 2.4 & 1.9 & 2.2 & 1.6 & 1.4 & 1.7 & 1.1 & 1.2 & 1.0 & 0.3 & $\star * \star *$ & NS & NS & NS & NS & NS & NS \\
\hline Spring & 5.5 & 5.8 & 5.2 & 5.6 & 4.6 & 5.5 & 5.7 & 4.0 & 4.3 & 3.0 & 4.9 & 3.0 & 0.9 & $\dagger$ & NS & NS & NS & $\dagger$ & NS & NS \\
\hline Summer & 5.7 & 4.2 & 5.5 & 4.3 & 4.4 & 5.0 & 7.3 & 4.7 & 4.7 & 5.1 & 5.5 & 4.2 & 0.6 & NS & NS & NS & * & NS & NS & NS \\
\hline Autumn & 3.2 & 1.7 & 3.0 & 1.0 & 3.7 & 1.9 & 3.7 & 2.1 & 4.4 & 2.2 & 3.9 & 1.1 & 0.5 & $\dagger$ & NS & NS & $\star \star \star$ & NS & NS & NS \\
\hline Total & 16.8 & 13.9 & 15.9 & 13.3 & 14.6 & 14.6 & 18.3 & 12.2 & 15.1 & 11.4 & 15.5 & 9.2 & 0.9 & NS & * & NS & $\star \star \star *$ & * & NS & NS \\
\hline $\mathrm{N}$ application & \multicolumn{2}{|c|}{345} & \multicolumn{2}{|c|}{334} & \multicolumn{2}{|c|}{270} & \multicolumn{2}{|c|}{359} & \multicolumn{2}{|c|}{294} & \multicolumn{2}{|c|}{317} & & & & & & & & \\
\hline
\end{tabular}

${ }^{1}$ Yield from establishment in March 2008 to Winter 2008/9 season

${ }^{\star * \star} \mathrm{P}<0.001,{ }^{\star \star} \mathrm{P}<0.01,{ }^{*} \mathrm{P}<0.05,+\mathrm{P}<0.1$ 
ha) and perennial ryegrass yield by $13 \%(1.9 \mathrm{t} \mathrm{DM} / \mathrm{ha})$ for Year 2, relative to unirrigated treatments.

\section{Milksolids production}

Mean MS yield for the 6 farmlets over 2 years was $1341 \mathrm{~kg}$ MS per ha (1 371 for perennial ryegrass and 1310 for tall fescue) after adjustments for the quantity of maize silage (brought in feed) used. The fat (mean $4.4 \%$ ) and protein (mean $3.5 \%$ ) composition of milk was similar between treatments.

\section{Discussion}

\section{Perennial ryegrass and tall fescue yield}

Despite similar total DM yields, there were differences in the timing of pasture growth within each year. Yield of perennial ryegrass from establishment to winter was approximately $70 \%$ greater $(1.7 \mathrm{t} \mathrm{DM} / \mathrm{ha})$ than tall fescue. Lower tall fescue winter yield in Year 1 was due to its slower establishment relative to ryegrass (Neal et al. 2009), despite 'Advance' tall fescue being one of the quicker fescue cultivars to establish (Fraser \& Lyons 1994). The greater yield of perennial ryegrass through the winter of Year 2, once established, suggests that perennial ryegrass has a lower temperature threshold for growth as compared with tall fescue. The yield of tall fescue in summer was $20 \%$ greater $(1 \mathrm{t} \mathrm{DM} / \mathrm{ha})$ than the yield of perennial ryegrass in Year 1. However, there was no difference in summer or autumn yield between species in Year 2, despite low levels of autumn rainfall (Table 1). Rollo et al. (1998) in a compilation of data from various trials, found a consistent production advantage to tall fescue over perennial ryegrass in summer of the first 2 years after establishment, however, the difference between tall fescue and perennial ryegrass yield in summer was small (mean $134 \mathrm{~kg} \mathrm{DM} / \mathrm{ha}$ (3\% increase)). These data suggest that tall fescue has a higher optimal temperature for growth compared with perennial ryegrass (temperature optimum for perennial ryegrass of $18^{\circ} \mathrm{C}$ (Kemp et al. 1999; Razmjoo et al. 1993)).

Irrigation increased the total yield of pasture by $30 \%(3.6 \mathrm{t} \mathrm{DM} / \mathrm{ha})$ in Year 2. The impact of irrigation was greater for tall fescue (50\% increase in DM yield) than perennial ryegrass ( $13 \%$ increase DM yield). The additional $2 \mathrm{t} \mathrm{DM} / \mathrm{ha}$ in perennial ryegrass yield from irrigation is similar to the $1-2 \mathrm{t} \mathrm{DM} /$ ha increase $(20 \%$ more DM) found by Thom et al. (2001). The higher irrigation yield response of tall fescue in the summer/ autumn highlights the likely suitability of tall fescue for regions with summer temperatures similar to or higher than those experienced in the Waikato.

\section{Milksolids yield}

Milksolids yield and profit determines the value of any DM production increases from these pastures. Milksolids yield will be reported at the conclusion of this 3-year study. At an assumed high feed conversion efficiency of $90 \mathrm{~kg}$ MS per $\mathrm{t}$ DM eaten (at the high end of commercial and research farm measures to date), it was estimated that the average farmlet herd consumed $14.9 \mathrm{t} \mathrm{DM} / \mathrm{ha}$ of pasture to produce $1341 \mathrm{~kg}$ MS per ha. Mean pasture production presented in Table 2 was $16 \mathrm{t} \mathrm{DM} / \mathrm{ha}$ for pasture only treatments (A and B), suggesting that an estimated $93 \%$ of pasture grown, as measured by cage cuts, was eaten. This brief analysis confirms that the cage cut estimates of pasture grown per ha probably underestimate the actual pasture growth and availability of feed.

\section{Conclusion}

Despite similar yields of tall fescue and perennial ryegrass in Year 1 and Year 2, there were differences in the timing of grass growth within each season with perennial ryegrass having a greater yield in winter, and tall fescue a greater yield in summer, although the yield advantage of tall fescue in summer was inconsistent between years. The high response of tall fescue to irrigation in the summer/autumn, relative to perennial ryegrass, highlights the suitability of tall fescue for regions with summer temperatures in excess of those experienced in Waikato, but also suggests that adequate soil moisture would be required through the summer for production to exceed perennial ryegrass. Interim results using cage cut data suggest that the treatments compared in this progress report failed to achieve a greater yield than the benchmark perennial ryegrass.

\section{ACKNOWLEDGEMENTS}

This work is part of a larger Pastoral 21 Feed research programme, which includes development and extension research in other regions of New Zealand. Thanks to the staff of Scott Farm for their valuable work.

\section{REFERENCES}

Ball, R. 1970. The use of nitrogenous fertilisers. II. Department of Scientific and Industrial Research experiments. Dairyfarming Annual. Massey University, Palmerston North. 72 pp.

Baars, J.A. 1976. Seasonal distribution of pasture production in New Zealand. IX. Hamilton. New Zealand Journal of Experimental Agriculture 4: 157161.

DairyNZ 2009. The strategy for New Zealand dairy farming 2009/2020. www.dairynz.co.nz

Fraser, T.J.; Lyons, T.B. 1994. Grasslands Advance tall fescue establishment and animal performance. Proceedings of the New Zealand Grassland Association 56: 120-177. 
Hewitt, A.E. 1998. New Zealand Soil Classification. Landcare Research Science Series No. 1. Lincoln: Manaaki Whenua, Landcare Research.

Kemp, P.D.; Matthew, C.; Lucas, R.J. 1999. Pasture species and cultivars. pp. 83-100. In: New Zealand pasture and crop science. Eds. White, J; Hodgson, J. Oxford University Press, Auckland.

Lee, J. M.; Donaghy, D. J.; Roche, J. R. 2008. Effect of defoliation severity on regrowth and nutritive value of perennial ryegrass (Lolium perenne L.) dominant swards. Agronomy Journal 100: 308-314.

Mitchell, K.J. 1963. Production potential of New Zealand pasture land. Proceedings of the New Zealand Institute of Agricultural Science: 80-96.

Neal, J.S.; Fulkerson, W.J.; Lawrie, R.; Barchia, I.M. 2009. Difference in yield and persistence among perennial forages used by the dairy industry under optimum and deficit irrigation. Crop and Pasture Science 60: 1071-1087.

Penno, J. 1999. Stocking rate for optimum profit. Proceedings of South Island Dairy Event 1: 25-41.
Razmjoo, K.; Kaneko, S.; Imada, T. 1993. Varietal differences of some cool-season turfgrass species in relation to heat and flood stress. International Turfgrass Society Research Journal 7: 636-642.

Roberts, A.H.C.; Morton, J. 1999. Fertiliser use on dairy farms: the principles and practice of soil fertility and fertiliser use on New Zealand dairy farms. New Zealand Fertiliser Manufacturers' Association Auckland, NZ. 36 pp.

Rollo, M.D.; Sheath, G.W.; Slay, M.W.A.; Knight, T.L.; Judd, T.G.; Thomson, N.A. 1998. Tall fescue and chicory for increased summer forage production. Proceedings of the New Zealand Grassland Association 60: 249-253.

Thom, E.R.; Burggraaf, V.T.; Waugh, C.D.; Clark, D.A. 2001. Effects of pasture species and irrigation on milk production over four summers in the Waikato. Proceedings of the New Zealand Grassland Association 63: 215-221. 
